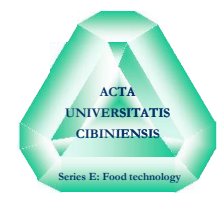

\title{
THE INFLUENCE OF STORAGE TIME ON THE YIELD OF ALCOHOL EXTRACTION FROM MARC
}

\begin{abstract}
Mihaela BALTEȘ1
PhD Fellow, SOP HRD/159/1.5/S/133675 Project, Romanian Academy Iasi Branch or "Lucian Blaga" University from Sibiu, Partner

Abstract: The influence of time on the yield of alcohol extraction from marc stored monitored and interpreted for 10, respectively 20, 40,60 and 80 days was investigated. The distillation of diffusion juice obtained through two fermentation variants led to the conclusion that a longer storage time leads to a drastic decrease of the alcohol level in marc. Thus, this valuable sub product evaporates, i.e. is lost. It was clear that the results were strongly connected, although the procedure differs from the point of view of the order of the technological succession.
\end{abstract}

Keywords: sweet marc, alcohol, fermentation time

\section{INTRODUCTION}

It is very important that marc is fresh, fermented and processed in the winemaking season in order to get higher yields of valuable substances as ttartaric acid, tannin, oil, alcohol, wheat middling's and oenocolouring (Novetschi and Mironescu, 2007). If this process cannot take place immediately, marc can be stored until the end of February of the following year at most (Banu et al. 2010, Cotea et al. 2010, Tița 2001, Tița 2004). Besides, the following conditions must be met: cement basins must be cleaned and sealed, their capacity must be equal to the capacity of the processing installation for 24 hours; marc must be very well dried and sulphited with about $150-200 \mathrm{mg} / \mathrm{kg}$, then the basins are sealed as tight as possible with sand (dirt) and polyethylene film.

Even if done in this condition, storing marc for about 6 months causes an about $50 \%$ decrease in yields of tartrates and alcohols as a result of the

\footnotetext{
${ }^{1}$ Corresponding author. Mailing address: University "Lucian Blaga" of Sibiu, Faculty of Agricultural Sciences, Food Industry and Environmental Protection, Str. I. Raţiu 7-9, 550012 Sibiu, Romania. Phone: 0040/269/211338. Fax: 0040269212558. E-mail address: mihaela.baltes@yahoo.com
} 
evaporation of alcohol and the triggering of unwanted fermentations: acrylic, propionic, acetic, simultaneously with an increase of the methanol content (Cotea 2009, Bulancea 1987, Tiţa 2001, Târdea et al.2010).

In the marc alcohol obtaining processes, both classical and modern procedures of complex marc processing are employed.

In order to obtain marc alcohol, people employ discontinues installations heated with indirect fire (non-immersed marc), directly heated with fire (immersed marc) or heated with indirect or direct steam.

In Romania, people mostly use installations with two, three or four stills heated directly with steam and equipped with a dephlegmator, which produce alcohol whose alcohol concentrations are between 50 and $80 \%$. Still, their productivity is rather low.

In medium and high capacity wineries or in complex marc processing units, vertical continuous distillation installations are employed. They work on the counter flow principle (steam bubbles at the bottom and marc circulates top down). This type of installations ensure increased mechanization and automation and a much higher productivity, thus obtaining a raw spirit of about $25 \%$ vol. alcohol which is to undergo redistillation. The aims of the paper is to monitoring the influence of storage time on the yield of alcohol extraction from marc. This paper analyses the influence of time on the yield of alcohol extraction from marc stored monitored and interpreted during 80 days. The values of the variants selected for study are validated through the ANOVA regression model.

\section{MATERIALS AND METHODS}

Sweet marc from the Sebeș wine center and the INDIS 400 continuous distillation installation were used. Working variants were:

- V1. Sweet marc, tartaric acid precipitation, fermentation, distillation. Storage time: 10 days (V1.1), 20 days (V1.2), 40 days (V1.3), 60 days (V1.4), 80 days (V1.5).

- V2. Sweet marc, fermentation, distillation, tartaric acid precipitation. Storage time: 10 days (V2.1), 20 days (V2.2), 40 days (V2.3), 60 days (V2.4), 80 days (V2.5).

The ANOVA regression model was used to validate the variants selected.

\section{RESULTS AND DISCUSSION}

Figure 1 shows that the values of the distilled obtained from marc varies according to the work variants used, but also to its storage time. In variants V1.1 the maximum amount of alcohol is distilled $(3,24 \mathrm{~L} / 100 \mathrm{~kg})$, while in variants V1.5 the values are minimum. 
The values recorded in variants V2.1 are 6,5\% lower than those in variants $\mathrm{V} 1.1$, which were significantly closer to the values of variants V1.2. In what regards variants $\mathrm{V} 3$, both extraction procedures recorded similar values of alcohol resulted from distillation $(2.14 / 2.16 \mathrm{~L} / 100 \mathrm{~kg})$.

The lowest alcohol values were recored in the case of variants V5.1 and V5.2, where the maximum amount of alcohol recorded was $1.33 \mathrm{~L} / 100 \mathrm{~kg}$ marc.

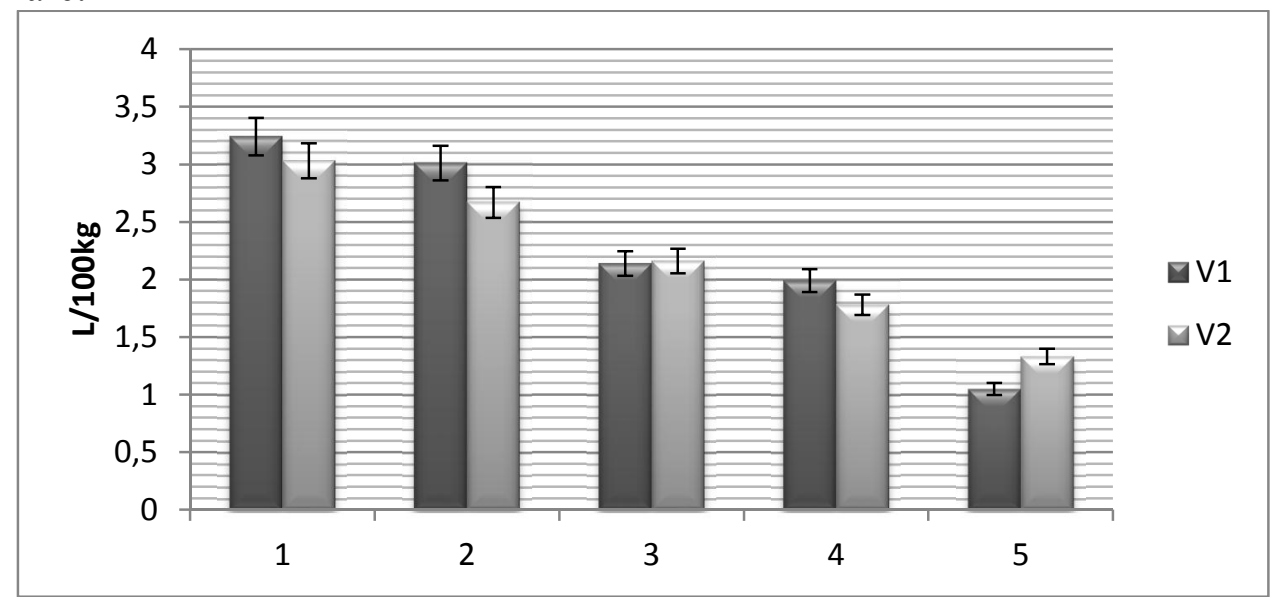

Figure 1. Alcohol obtained after distillation of marc stored for 10, respectively 20 , 40, 60 and 80 days in the two diffusion juice obtainment variants (V1. Sweet marc, tartaric acid precipitation, fermentation, distillation) and (V2. Sweet marc, fermentation, distillation, tartaric acid precipitation)

The objective of ANOVA regression (Table 1) is to determine whether there is a significant difference between the two variants, V1 and V2. In this case, the correlation report $\mathrm{R}$ (Multiple $\mathrm{R}$ ) is 0.996647 , the determination degree $\mathrm{R}^{2}$ ( $\mathrm{R}$ square) is 0.993305 , the adjusted values of the determination coefficient Adjusted $\mathrm{R}$ square is 0.743305 , the standard deviation of the sample errors $\left(\mathrm{s}_{\mathrm{u}}\right)$, standard error of 0.221079 , the sample number $(\mathrm{n})$ is 5 .

The data in the ANOVA table show that the variation caused by regression presents the following:

$\mathrm{SS} /$ the sum of squares is 29.0044 , the mean square MS is 29.0044 , the value of test $\mathrm{F}$ is 593.4297 and $\mathrm{F}$ means 0.000152 . This value is lower than 0.05 , thus it rejects $\mathrm{H}_{0}$ - the valid model. The correlation report $\mathrm{R}$ shows that the two variants we worked with are strongly connected. The determination degree $\mathrm{R}^{2}$ proves that $99 \%$ of tests are viable for both the variants we worked with. The fact that the standard deviation $\left(\mathrm{s}_{\mathrm{u}}\right)$ is close to 0 means that all the points are on the regression line. It is also ascertained that the P-value $=$ $1.68 \mathrm{E}-05$. This value is lower than 0.05 , therefore the coefficient is important in the data analysis. The F test, calculated to validate the regression model, is 593.4297, while the significance threshold $=0.000152$. This value is under 
0.05 , thus the regression model is valid and can be used to analyse the dependency between the two variants.

Table 1 . The results of the regression analysis

\begin{tabular}{|c|c|c|c|c|c|c|}
\hline \multicolumn{7}{|c|}{ SUMMARY OUTPUT } \\
\hline \multicolumn{7}{|c|}{ Regression Statistics } \\
\hline Multiple R & 0,996647 & & & & & \\
\hline R Square & 0,993305 & & & & & \\
\hline $\begin{array}{l}\text { Adjusted R } \\
\text { Square }\end{array}$ & 0,743305 & & & & & \\
\hline $\begin{array}{l}\text { Standard } \\
\text { Error }\end{array}$ & 0,221079 & & & & & \\
\hline Observations & 5 & & & & & \\
\hline \multicolumn{7}{|l|}{ ANOVA } \\
\hline & $d f$ & $S S$ & $M S$ & $F$ & \multicolumn{2}{|l|}{$\begin{array}{c}\text { Significance } \\
F\end{array}$} \\
\hline Regression & 1 & 29,0044 & 29,0044 & 593,4297 & \multicolumn{2}{|l|}{0,000152} \\
\hline Residual & 4 & 0,195504 & 0,048876 & & & \\
\hline \multirow[t]{2}{*}{ Total } & 5 & 29,1999 & & & & \\
\hline & Coefficients & $\begin{array}{l}\text { Standard } \\
\text { Error }\end{array}$ & t Stat & P-value & Lower 95\% & $\begin{array}{l}\text { Upper } \\
95 \%\end{array}$ \\
\hline Intercept & 0 & $\# \mathrm{~N} / \mathrm{A}$ & $\# \mathrm{~N} / \mathrm{A}$ & $\# \mathrm{~N} / \mathrm{A}$ & $\# \mathrm{~N} / \mathrm{A}$ & \#N/A \\
\hline X Variable 1 & 1,057975 & 0,04343 & 24,36041 & $1,68 \mathrm{E}-05$ & \multirow[t]{2}{*}{0,937394} & 1,178557 \\
\hline \multicolumn{5}{|c|}{ RESIDUAL OUTPUT } & & \\
\hline Observation & Predicted $Y$ & Residuals & $\begin{array}{l}\text { Standard } \\
\text { Residuals }\end{array}$ & & Percentile & $Y$ \\
\hline 1 & 3,205666 & 0,034334 & 0,173635 & & 10 & 1,05 \\
\hline 2 & 2,824794 & 0,185206 & 0,936617 & & 30 & 1,99 \\
\hline 3 & 2,285227 & $-0,14523$ & $-0,73444$ & & 50 & 2,14 \\
\hline 4 & 1,883196 & 0,106804 & 0,540125 & & 70 & 3,01 \\
\hline 5 & 1,407107 & $-0,35711$ & $-1,80595$ & & 90 & 3,24 \\
\hline
\end{tabular}

$\mathrm{V} 1=\mathrm{X}, \mathrm{V} 2=\mathrm{Y}$

Figures 2, 3 and 4 present the regression line for the selected variant, the evolution of V1 variant and the predictive evolution of V1 variant. 


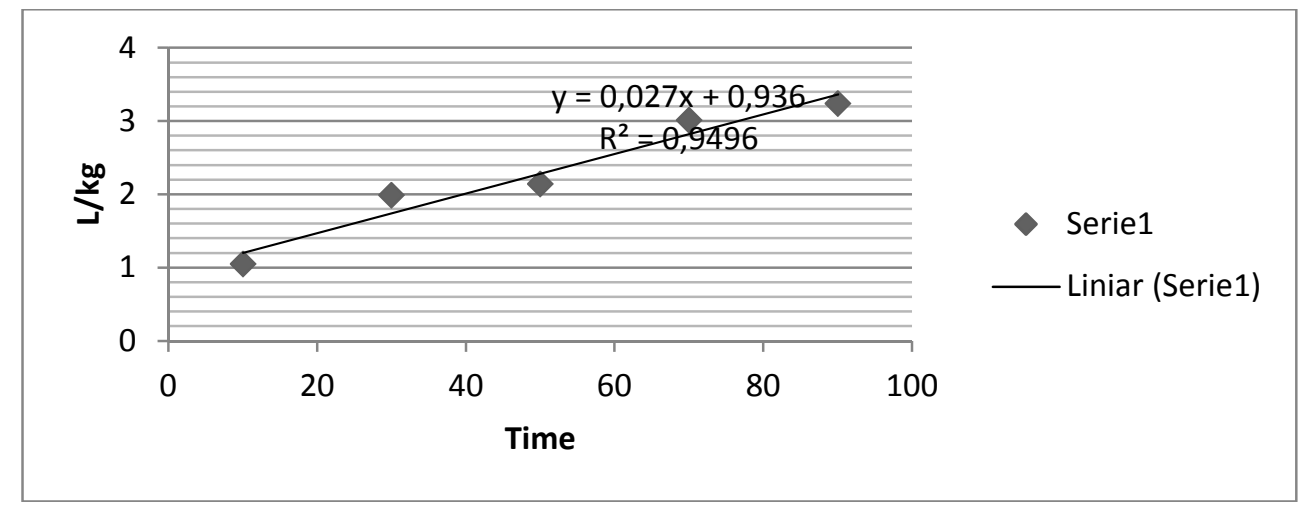

Figure 2. The regression line for the selected variant

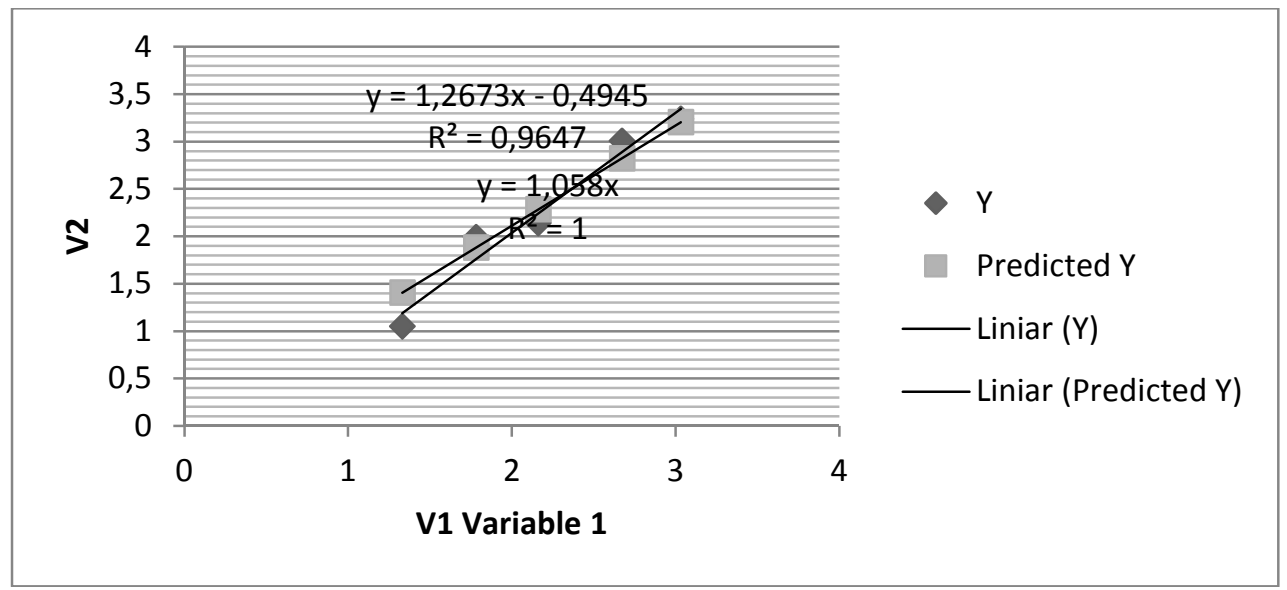

Figure 3. The evolution of V1 variant



Figure 4. The predictive evolution of V1 variant 


\section{CONCLUSIONS}

The alcohol resulted from marc distillation depends on the following factors: storage time and the selected work variants. From the point of view of yield, it is recommended to use a short storage time, because a longer storage time causes the alcohol to evaporate. Regarding the diffusion juice extraction procedure, it is recommended to select variants V1, which means: Sweet marc, tartaric acid precipitation, fermentation, distillation. The regression models established based on the results obtained are valid and can be used to analyse from this point of view to the correlations between the two variants selected to be studied.

\section{ACKNOWLEDGEMENTS}

This paper is supported by the Sectoral Operational Programme Human Resources Development (SOP HRD), financed from the European Social Fund and by the Romanian Government under the contract number POSDRU/159/1.5/S/133675.

\section{REFERENCES}

1. Banu C., (2010), Manualul inginerului de industrie alimentară, Editura Tehnică, Bucureşti.

2. Bulancea, M.,(1987), Tehnologia şi utilajul industriei vinului şi a băuturilor alcoolice distilate, Vol. I şi II, Galaţi

3. Cotea, V.D., (2009), Tratat de oenologie, Vol. I, Editura Ceres, Bucureşti.

4. Cotea, V.D., (2009), Tratat de oenologie, Vol. II, Editura Ceres, Bucureşti.

5. Cotea, V., Pomohaci, N., Gheorghiţă, M., (2010), Oenologie, Editura Didactică şi Pedagogică, Bucureşti.

6. Novetschi I., Mironescu M. (2007), Research on using natural dyes, Proceedings International Conference "Agricultural and Food Sciences, Processes and Technologies" Third edition, Sibiu, 241-244

7. Tiţa Ovidiu, (2001), Tehnologia, utilajul şi controlul calităţii produselor in industria vinului, Volumul I, Editura "Lucian Blaga" din Sibiu.

8. Tiţa Ovidiu, (2001), Tehnologia, utilajul şi controlul calităţii produselor in industria vinului, Volumul II, Editura "Lucian Blaga" din Sibiu.

9. Tiţa, O., (2004), Manual de analiză şi control tehnologic în industria vinului, Editura Univ. Lucian Blaga, Sibiu.

10. Țârdea, C., Sârbu, Ghe., Țârdea, A., (2010), Tratat de vinificaţie, Editura Ion Ionescu de la Brad, Iaşi. 